\title{
Magyarország határátkelőinek térökonometriai elemzése
}

\author{
Hazánk és a közvetlen szomszédságában elhelyezkedő országok köz- \\ ti, illetve a Magyarországot tágabb értelemben körülvevő nemzetközi \\ gazdasági centrumok kapcsolatának értékelése szempontjából a ha- \\ tárátkelők, mint az országhatár okozta elválasztó hatás csökkentésére \\ szolgáló eszközök, vizsgálata kiemelten fontos tényező. A hazai gaz- \\ dasági és társadalmi müködési folyamatok területén a történelmi és \\ kulturális viszonyok miatt kiemelkedő a határon átnyúló együttmü- \\ ködések jelentősége. ${ }^{1}$
}

DOI 10.24228/KTSZ.2018.4.4

\section{Szabó Zsombor - Török Árpád}

Budapesti Múszaki és Gazdaságtudományi Egyetem - Közlekedés és Jármúmérnöki Kar e-mail:szabo.zsombor@mail.bme.hu torok.arpad@mail.bme.hu

\section{BEVEZETÉS}

$\mathrm{Az}$ országhatárok vizsgálata napjainkban kiemelt jelentőségű. Míg az európai kutatások elsődleges célja az együttmüködések jellegének minél világosabb feltárása, addig a világ többi részén a fókusz a nemzetközi együttműködések gazdaságra gyakorolt hatásán van. Jelen kutatás kiemelt célja a határok, a határmenti régiók, illetve a határátkelők jellemző paraméterei és a keresztező forgalom nagysága közötti kapcsolatrendszer leírása. Számos nemzetközi döntés-előkészítő, illetve helyzetfeltáró tanulmány [16], [17] világosan megmutatta, hogy a határátkelők elhelyezkedése, egymáshoz való viszonya, illetve a kapcsolódó közlekedési igények értékelése során kiemelkedő súllyal célszerü

1 A szerzők ezúton szeretnék megköszönni azon önkormányzatok hozzájárulását, akik megkeresésükre az adatokhoz való hozzájárulást vagy adatokat biztosítottak: Abaújvár, Esztergom, Gönc, Lipót, Sopron és Sopronkövesd figyelembe venni a határkapcsolatot biztositó úthálózat jellemzőit (pl. úttípus, nemzetközi úthálózat, speciális műszaki létesítmények: alagút, híd, stb.), a szomszédos országok közti kapcsolat sajátosságait, különös tekintettel a speciális nemzetközi egyezmények hatására kialakuló ellenőrzés nélküli határvonalakra. ${ }^{2}$

A téma jelentőségét és aktualitását mutatja, hogy válogatva az MTI (Magyar Távirati Iroda) híreiből, számos cikkre bukkanhatunk, amelyek a szomszédos országokkal kapcsolatot teremtő új szükséges határátkelőkre vonatkoznak [22]. Kiemelt probléma, hogy míg hazánkban 25 kilométerenként van egy határátkelő, addig ez a szám Nyugat-Európában öthat körül alakul.

2 A schengeni rendszer alatt jelen cikkben azon vizsgált országok csoportját értjük, akik alkalmazzák az 1985-ben bevezetett schengeni egyezményt, amely többek között eltörölte a részt vevő államok közötti határellenőrzést. 


\section{Közlekedésgazdaság}

\section{1. ábra: Határátmenet-fejlesztések a 2014-2020-as ciklusban \\ (forrás: MTI közszolgálat [22] alapján saját szerkesztés)}

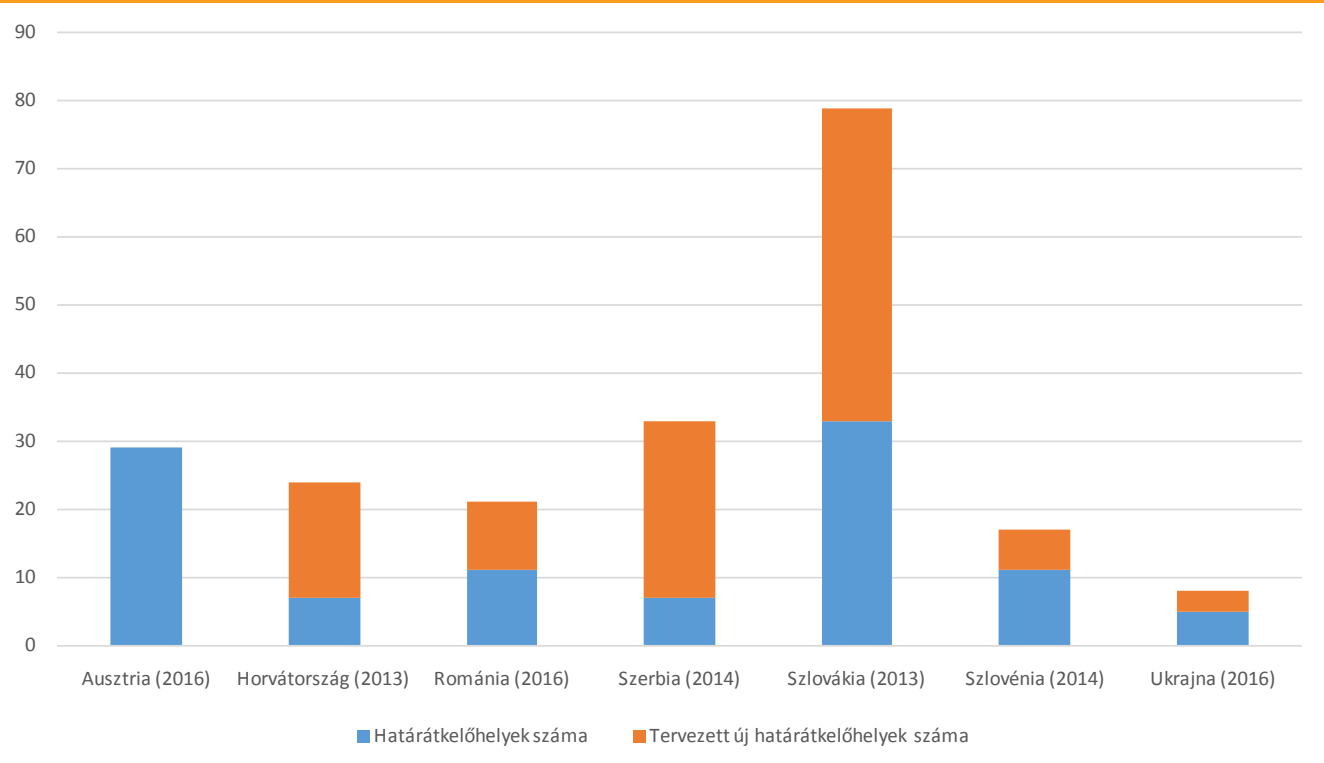

$\mathrm{Az}$ 1. ábra Magyarország és a szomszédos országok között jelenleg működtetett és a jövőben tervezett határátkelőhelyek számát mutatja be. Zárójelben a megállapodás évét tüntettük fel. Mint az látható Ausztria esetében még az új határátkelőhelyek száma nem került meghatározásra, csupán az emelésre vonatkozó célkitüzéseket rögzítették.

Európát, és ezen belül is Közép-Európát tekintve a határok helyzete speciálisnak tekinthető, hiszen az itt húzódó határvonalak 97,4 százaléka a 19. század folyamán megváltozott, csupán a Románia és Bulgária közti természetes határvonal, a Duna nem változott az említett időszakban. A történelmi határok jelentős része földrajzi egységekhez kötődött, ami azonban napjainkban már nem mondható el, hiszen a Kelet-Közép-Európát jellemző jelenlegi határok 55 százaléka nem köthető természetes földrajzi egységhez [4]. Emiatt az európai határmenti kutatások az akadályok vizsgálata helyett az úgynevezett eurorégiók, vagyis határon átnyúló nemzetközi regionális együttműködések gazdasági hatásaival foglalkoznak.
Mindezek alapján jelen kutatás célja egy olyan eszköz kialakítása, amely alkalmas az elkészült, valamint tervezett határátmenetek megfelelőségének vizsgálatára. A bemenő adatokat a Magyar Közút Nonprofit Zrt. 2015-ös keresztmetszeti forgalmakat közreadó kiadványa biztosította [15]. Ezen kívül számos adatot online internetes oldalról értünk el (rendőrség, Wikipédia, Google Maps), illetve felhasználtuk az Egységes Hídnyilvántartási Rendszert [23] és Magyarország Helységnévtárát [24], valamint a szlovák közút (SSC - Slovenská správa ciest) adatbázisát [25].

\section{A MODELL ISMERTETÉSE}

\subsection{A modell lehatárolása}

A modellben Magyarország közúti határátkelőit térökonometriai módszerekkel vizsgáltuk. Ehhez eredményváltozóként a határátkelők kétirányú forgalmát vettük figyelembe egységjármü/nap/két irány mértékegységgel. A vizsgált időszakban (2015.) 103 db határátkelőhely volt Magyarországon, ezek elhelyezkedését mutatja a térkép (2. ábra). 


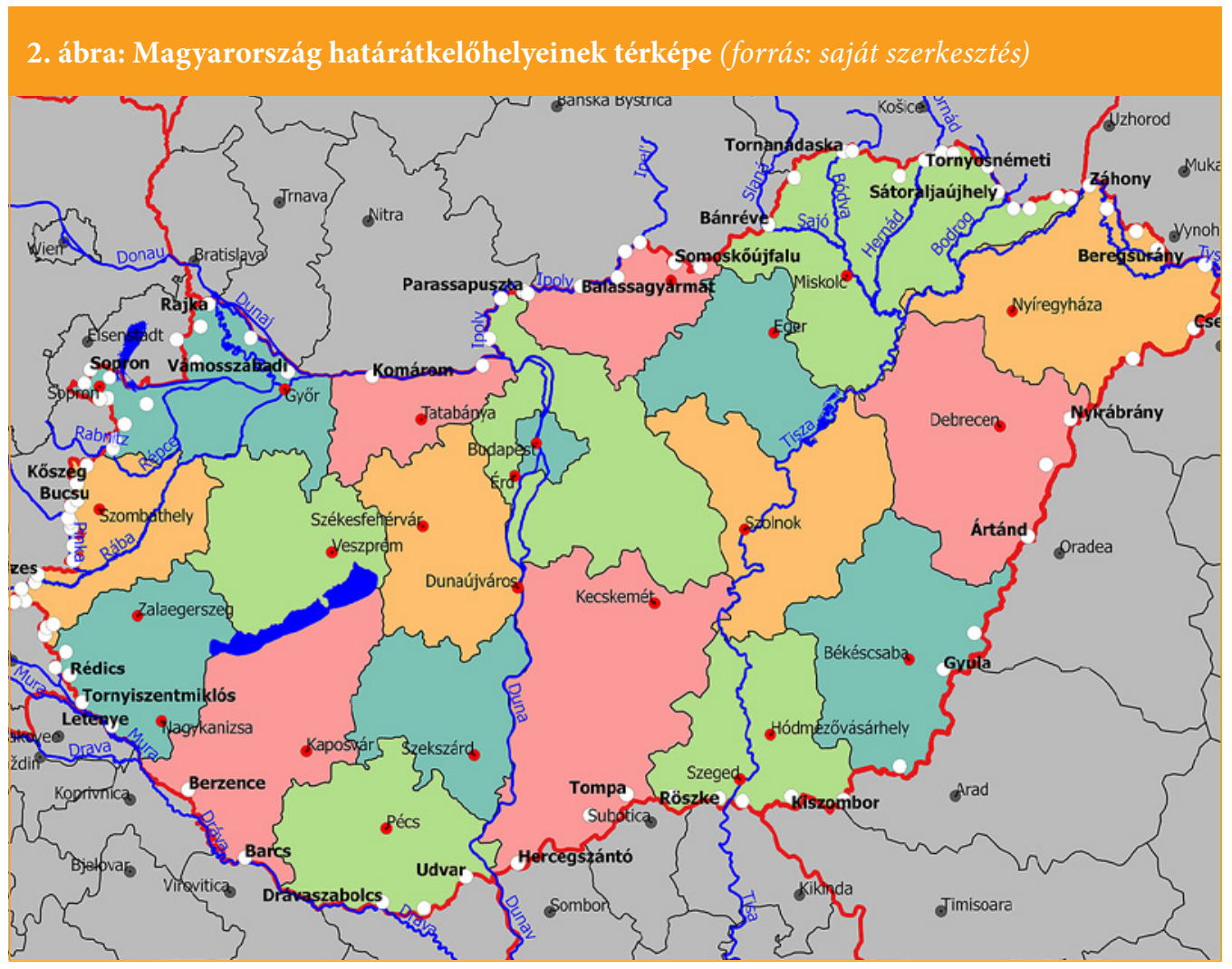

\subsection{A modell felépítése}

\subsubsection{A fö probléma magyarázóváltozói}

Amint az már a bevezetőben szerepelt, jelen vizsgálat számos fontos kérdésre keresi a választ. E fejezetben a vizsgálathoz szükséges paraméterek kerülnek bemutatásra. A megvizsgált döntés-előkészítő tanulmányok áttekintése után a kutatás fö célja a vizsgált hazai határátkelőkön jelentkező forgalmi igények becslésére alkalmas modell azonosítása. Fontos hangsúlyozni, hogy a közlekedésmodellezésben a forgalom ráterhelés során széles körben alkalmaznak regressziós becsléseket, ezért e módszertani keretek jelen elemzés során is megfelelőnek minősíthetők [6].

E modellek azonban a térbeli összefüggéseket nem vizsgálják, noha ez a tényező jelen esetben nem elhanyagolható. Ennek oka, hogy esetünkben nem egy egyszerü útvonalválasztási problémát vizsgálunk, tekintve, hogy olyan kölcsönhatásokat is szeretnénk tetten érni modellünkkel, amelyek esetében a térben egymáshoz közelebb elhelyezkedő egységek vonatkozásában az egymásra hatás intenzitása erősebb (pl. szolgáltatásfejlesztés igénykeltő hatása - a határátkelőhelyek és kapcsolataik kapacitásbövítése a teljes határszakaszra irányuló összes mobilitási igényre élénkítő hatást gyakorolhat).

A feltárt szakirodalom alapján a regressziós vizsgálat során az alábbi tényezőket mindenképpen célszerü a magyarázóváltozók között vizsgálnunk ([16], [17]):

- híddal való ellátottság,

- út típusa,

- európai utak hálózata,

- célország,

- schengeni-határok.

Az előzetes vizsgálatok eredményei alapján a schengeni határok és a célország oly mérték- 


\section{Közlekedésgazdaság}

ben függnek össze, hogy a dummy változók sajátosságai miatt külön nem vonhatók be a modellbe.

A híddal való ellátottságot két tényező vizsgálja. Az egyik egy dummy változó, amelynek értéke akkor 1 , ha a határ egy hídon van. A másik tényező pedig a határfolyók mérete és a hidak forgalma közti összefüggés leképezésére irányul. A második tényező figyelembevétele azért lehet indokolt, mert a nagyobb folyók esetében a nagyobb hídépítési költségek miatt a kapcsolatok vélhetően jóval ritkábbak, de jelentősebbek. Így további három változó került be a hidak tekintetében. Az egyik a folyók felett átívelő híd, míg a másik kettő a folyók határmenti, illetve teljes hossza.

Az utak típusát, a kategóriaváltozók miatt, szintén dummy változók reprezentálják. Itt a viszonyítási alapot az önkormányzati kezelésű utak jelentik. Szintén ebbe a körbe vonható az európai utak esete, azonban itt a változók kialakítása egy fokkal bonyolultabb összefüggést követ. Az európai utak rangsorolása a következő: az A osztályú főutak kelet-nyugati (tízzel osztható számok pl.: E60), illetve északdéli irányban (öttel osztható számok pl.: E65, E75) kötik össze Európa egyes részeit. Ezeket egészítik ki az A osztályú összekötő (egyéb kétszámjegyű), illetve a B osztályú (három számjegyü) utak. Ennek megfelelően az európai utak hatását három változóba kódoltuk. Az egyes változók azt mutatják, hogy a határátmenet hány, adott típusú európai út része.

Az utolsó szempont a célország. Itt azt vizsgáltuk, hogy az adott határátkelőn Magyarországról kilépve melyik országba lehet belépni. A kategóriaváltozók miatt itt is dummy változókat alkalmaztunk, amelyeknek a viszonyítási pontja ebben az esetben Ukrajna volt.

\subsubsection{Egyéb magyarázóváltozók}

A határátkelöhelyek közlekedés-szempontú elemzése a jelenlegi kutatásokban leginkább

3 Dummy alatt jelen cikkben azon bináris változókat értjük, amelyek akkor vesznek fel egyet, ha az adott tulajdonság az adott vizsgált egyedre igaz. az áruszállításra koncentrál. Ennek oka, hogy a közlekedési költségek egyik fontos eleme a határátkelöhelyek okozta veszteség, ami leginkább a teherszállításban érhető tetten. Az áruszállításban ugyanis a tehergépjármü legkisebb idővesztesége is hatalmas kiesést okozhat, ami hosszú távon a kereskedelmi kapcsolatok leépülését vagy átterelődését eredményezheti.

A határkeresztezés költségnövekedéssel jár, aminek okai a késés, a vámvizsgálat, a megengedhető legnagyobb tömeg szabványának változása, illetve a közlekedési mód közti váltás. Így leggyakrabban dummy változóval szokás modellezni, ami akkor vesz fel egyet, ha a kiindulási és a célhelyszín határral van egymástól elválasztva, például [12]. A határon át történő szállítást megkönnyítik a nemzetközi egyezmények, a technológiai fejlődés, a szállítási infrastruktúra, az integrált közlekedési hálózatok, valamint a „földrajzi akadálymentesség" (smooth geography) [2].

A publikált cikkek a határátkelők tanulmányozása során fóképp az amerikai-kanadai kapcsolatokra fókuszálnak. A NAFTA (NorthAmerican Free Trade Agreement - Észak-amerikai Szabadkereskedelmi Egyezmény) keretrendszerének köszönhetően Kanada, illetve Kanadán belül kiemelten Ontario a legjelentősebb kereskedelmi partnerei az Amerikai Egyesült Államoknak. A kutatás alapja, hogy Ontario állam és az USA között többnyire hidakon keresztül folyik a forgalom [8]. Ezek a hidak azonban túlterheltek, köszönhetően többek között annak, hogy Ontario az USA negyedik legnagyobb kereskedelmi partnere [8]. Mindez alátámasztja jelen cikk egyik célkitüzését, hogy amennyiben egy határátkelő híd formájában épült meg, befolyásolja-e a határforgalmat?

$\mathrm{Az}$ amerikai és kanadai kutatások nagy része vizsgálja továbbá azt, hogy milyen hatással van a várakozási idő a gazdasági mutatókra. Különösen a szeptember 11-i terrortámadások után a várakozási idő jelentősen megnőtt a határátkelőhelyeken. [9] cikkében egy olyan modellt épít, amelyben mérhetők ezen hatások. Itt az USA és Kanada közötti 15 db legforgalmasabb határátkelő forgalmi adatait vizsgálja, 1972 és 2011 között. A vizsgálat során, egy idősoros 
adatokon alapuló többváltozós lineáris regresszió került alkalmazásra, a magyarázóváltozók két csoportba sorolásával. A folytonos változók csoportjába sorolta az Egyesült Államok GDP-jét, az autógyártás mértékét ÉszakAmerikában, az amerikai és a kanadai dollár közti árfolyamot és a két országban jellemző üzemanyagárat. A tanulmány három dummy változót határozott meg:

- 9/11 hatása (a 2001. szeptember 11. terrortámadás rövidítése), amely változó akkor 1 , ha a 2001-es évet vizsgáljuk,

- 9/11 utáni akkor 1, ha az adott év nagyobb, mint 2001

- a gazdasági válság hatását, amelynek változója akkor 1, ha az adott év 2009 utáni.

A modelleket pedig a két irányra, illetve területspecifikusan is felépítették. Az eredményekből látszik, hogy a határátkelések szigorítása jelentős mértékben csökkentette a határon átkelő tehergépjármüvek számát, azonban a 2008-as gazdasági világválság is jelentősen csökkentette a forgalmat.

A bemutatott nemzetközi kutatások modellalkotó magyarázóváltozói megfelelők lehetnek a modell pontosítása szempontjából, azonban sok esetben ezek vagy országspecifikus tényezők, amelyeket már reprezentál a vonatkozó dummy változó, vagy pedig alkalmazásuk elsősorban idősoros adatként célszerü, azonban az ez irányú vizsgálatok nem tartoznak jelen cikk tárgykörébe. Közvetetten azonban, számos új magyarázóváltozót lehet bevezetni. $\mathrm{Az}$ amerikai példákon keresztül látszik, hogy egyrészt a kapacitás igencsak döntő a határátkelőhely forgalmának meghatározása esetén, így modellünket bővítettük ezen adatokkal. Noha valószínüleg a kihasználtsági adatok közvetlenebb módon befolyásolnák a forgalmi adatokat, mint a kapacitásadatok, azok magas korrelációja a forgalommal megakadályozza a használhatóságukat.

Szintén új változóként vonjuk be a súlykorlátozás értékét. Mivel a határátkelők forgalmának meghatározó része a teherszállításhoz köthető, így egyáltalán nem mindegy, hogy az adott útra milyen korlátozás vonatkozik. A maximális kapacitás az úthálózaton 44 ton- na. Ennek oka, hogy ma Magyarországon a megengedett legnagyobb össztömeg 40 tonna, viszont a negyven lábas konténerek esetében 44 tonna. Ezen határ felett pedig már csak külön engedéllyel közlekedhetnek járművek. 2013. július 1-jével a 209/2013. (VI. 18.) kormányrendelet értelmében a nehéz tehergépjármüvek csak gyorsforgalmi úton vagy fóútvonalon közlekedhetnek, így az egyéb utak esetében, ahol más korlátozás nincs megadva, a 12 tonnás határ került beállításra. Azokon az útvonalakon, ahol sem az áruszállítás, sem az autóbusz-közlekedés nem engedélyezett, ott a korlát 3,5 tonna, természetesen amennyiben más korlát nincs.

A kapacitással némiképp összefüggő paraméter az egyes határátkelők nyitva tartásának a kérdése. A schengeni határokon ez nem jelent problémát, azonban a többi esetben szignifikáns befolyása lehet. A nyitva tartás heti bontásban került vizsgálatra, ami azért szükséges, hogy a célok között megfogalmazott, a románmagyar határon nyitott, új határátkelőhelyek modellbe vonása is elvégezhető legyen a későbbi kutatásokban.

A határátkelők vizsgálata során mindenképp szükséges kitérni a határmenti lakosság kérdéskörére is. Általánosságban elmondható, hogy nagyvárosok környékén magasabb a határforgalom mértéke (például: Sopron, Bratislava (Pozsony)), azonban e városok nem közvetlenül a határ mellett fekszenek (például: Szeged, Oradea (Nagyvárad)). Emiatt a határvárosok lakossága mellett, érdemes más, nagyobb, területi egység lélekszámát is vizsgálni. Az Európai Unió a határmenti régiók megállapítása esetében a NUTS-3-at veszi alapul, emiatt ez lesz a modell egyik magyarázóváltozója. Azt is figyelembe kell venni, hogy Magyarország esetében a 19 megyéből 14 határmentinek számít. Emiatt érdemes lehet egy finomabb felbontást is alkalmazni, ami a járási szint [4]. Mivel a szomszédos országok esetében sok helyen hiányzik a LAU-1-es felbontás, így ezt csak hazai szinten lehet alkalmazni.

\subsubsection{Klasszikus lineáris regresszió}

A multikollinearitás elkerülése végett, az egymással korreláló magyarázóváltozók kiszürése 


\section{Közlekedésgazdaság}

\begin{tabular}{|c|c|c|c|c|c|}
\hline & & Együttható & Std. Hiba & $\operatorname{Pr}(>|t|)$ & \\
\hline \multicolumn{2}{|l|}{ Tengelymetszet } & 2280 & 4271 & 0,5951 & \\
\hline \multirow[t]{3}{*}{ Magyar lakosságszám } & Megye & $3,11 \mathrm{E}-03$ & $1,67 \mathrm{E}-03$ & 0,0669 & . \\
\hline & Járás & $-3,53 \mathrm{E}-03$ & $8,28 \mathrm{E}-03$ & 0,6714 & \\
\hline & Település & $1,66 \mathrm{E}-01$ & $3,84 \mathrm{E}-02$ & $4,64 \mathrm{E}-05$ & $* * *$ \\
\hline \multicolumn{2}{|c|}{ Szomszédos NUTS-3 régió lakossága } & $2,13 \mathrm{E}-03$ & $3,99 \mathrm{E}-03$ & 0,5947 & \\
\hline \multirow[t]{5}{*}{ Határátkelő tulajdonságai } & Nyitva tartás & $-12,49$ & 14,88 & 0,4040 & \\
\hline & Kapacitás & $-0,46$ & 0,43 & 0,2840 & \\
\hline & Összsúly korlát & 14,47 & 19,81 & 0,4675 & \\
\hline & Tehergépjármü korlátozás & 1098 & 931,3 & 0,2422 & \\
\hline & Autóbusz korlátozás & -1483 & 1170 & 0,2089 & \\
\hline \multicolumn{2}{|l|}{ Híd } & -550 & 798 & 0,4928 & \\
\hline \multirow{6}{*}{$\begin{array}{l}\text { Országra kategória dummy } \\
\text { változók }\end{array}$} & Ausztria & 5467 & 2004 & 0,0080 & ** \\
\hline & Horvátország & -1107 & 1914 & 0,5647 & \\
\hline & Románia & 809,4 & 1863 & 0,6652 & \\
\hline & Szerbia & $-180,2$ & 1899 & 0,9247 & \\
\hline & Szlovákia & 1628 & 2294 & 0,4801 & \\
\hline & Szlovénia & 4331 & 2199 & 0,0526 & . \\
\hline \multirow{3}{*}{$\begin{array}{l}\text { Európai nemzetközi E-út } \\
\text { hálózat }\end{array}$} & A osztályú fő́t & 4190 & 1592 & 0,0103 & * \\
\hline & A osztályú kiegészítő & -631 & 1348 & 0,6411 & \\
\hline & B osztályú & 1921 & 1826 & 0,2961 & \\
\hline \multirow{4}{*}{$\begin{array}{l}\text { Magyar úthálózat dummy } \\
\text { változói }\end{array}$} & Autópálya & 8434 & 3458 & 0,0171 & * \\
\hline & Autóút & 4580 & 3797 & 0,2315 & \\
\hline & Főút & 2641 & 1282 & 0,0429 & * \\
\hline & Egyéb & 828,8 & 955 & 0,3883 & \\
\hline \multirow{4}{*}{$\begin{array}{l}\text { Szomszédos országok útháló- } \\
\text { zatának dummy változói }\end{array}$} & Elsőrendű föút & -2420 & 3123 & 0,4409 & \\
\hline & Másodrendű föút & -3717 & 3150 & 0,2418 & \\
\hline & Összekötő út & -5042 & 3231 & 0,1229 & \\
\hline & Helyi út & -5601 & 3223 & 0,0864 & \\
\hline \multicolumn{2}{|l|}{ Folyószélesség } & 4,16 & 3,73 & 0,2680 & \\
\hline & $\mathrm{R}^{2}$ & 0,7757 & & & \\
\hline & F-statisztika p-értéke & $1,38 \mathrm{E}-14$ & & & \\
\hline
\end{tabular}

után felállításra került az alapmodell, amelynek paramétereit az 1. táblázat tartalmazza. A magyarázó- és az eredményváltozók közti korrelációértékeket szemléltető táblázat terjedelmi okok miatt jelen cikknek nem képezi részét. A multikollinearitás kiszürésével viszont lehetőségünk van az egymással összefüggő modell változók együttes figyelembevételének elkerülésére (pl. a heti nyitva tartási idő és a határátkelő korlátozására vonatkozó dummy változó között az $\mathrm{R}^{2}$ érték 0,8938 , így nem szerepelhetnek egy modellben).

Az 1. táblázat első oszlopa a modell által vizsgált magyarázóváltozókat tartalmazza, a második a vonatkozó együtthatókat, míg a harmadik a kapcsolódó p-értékeket, vagyis azt a szignifikanciaszintet, amely mellett el lehet 


\section{Közlekedésgazdaság}

fogadni az adott változó nulla értékére vonatkozó nullhipotézist. (. ha $\mathrm{p}<0,1,{ }^{\star}$ ha $\mathrm{p}<0,05,{ }^{*}$ ha $\mathrm{p}<0,01$, és ${ }^{* *}$ ha $\left.\mathrm{p}<0,001\right)$

Összevetve a táblázatot a magyarázóváltozókat leíró bekezdések tartalmával (2.2.1, 2.2.2 fejezetek), látható, hogy egyes korábban említett paraméterek nem képezik a modell részét. Az egyik ilyen a határ túloldalán fekvő település lakosságszáma. Ennek oka, hogy az első alapmodell eredménye szerint az együttható értéke nagy valószínüséggel 0 , illetve az ettől való eltérést nagy valószínüséggel a véletlen okozza (1-hez közeli p-érték). Bár a modellben maradtak magas p-értékkel jellemezhető együtthatók, ezek egy meghatározó része dummy változó, amelyek a szomszédos országok szerepének összehasonlításához szükséges relatív súlyokat reprezentálnak, emiatt a modellben ezeket célszerü továbbra is megjeleníteni. Például Szerbia vagy Ukrajna esetében, ahol a p-érték 0,9 felett van, arra utal a magas p-érték, hogy a határforgalomban nincs szignifikáns eltérés, csak azért, mert a határátkelő Szerbia vagy Ukrajna felé biztosít átjárást. Azonban a határ túloldalán fekvő település nem dummy változó, és a kirívóan magas p-értékének (nagyobb, mint 0,9 ) köszönhetően eltekinthetünk a tényező további vizsgálatától.

A másik fontos változtatás, hogy mind a hazai, mind a szomszédos országok úthálózatának reprezentálásánál az egyes csoportokat összevontuk. A külföldiek esetében ez az autópályára és az autóutra vonatkozik. Ennek oka, hogy Magyarországon minden autópálya és autóut a szomszédos országban autópályaként folytatódik, illetve ez visszafelé is igaz. Minden külföldröl érkező autópálya Magyarországon gyorsforgalmi útként folytatódik, így ezen adatok összefüggnek egymással. Magyarországon pedig a külterületi föutakat (nem gyorsforgalmi utakat) két csoportra a számozott és a nem számozott utakra (a KRESZ szabályainak megfelelően jelezve van-e zöld táblával az út száma a helyszínen) bontottuk. Ugyanis a csoportokon belüli forgalomnagyságban nem található szignifikáns eltérés. (A modell együtthatói nem mutattak jelentős különbséget). Ennek oka, hogy a határt elérő elsőrendủ főutak 36 százalékával fut párhuzamosan gyorsforgalmi út, amely elszívja a forgalmat, míg a másodrendü utak esetében hasonló elszívó hatást eredményező helyzet nem áll fenn. A számmal nem jelölt föutak csoportjában az eltérés hiányát az okozhatja, hogy a jármüvezetők valószínüleg nem tesznek különbséget az összekötő és a bekötő utak között (nincs szignifikáns érzékelhető különbség).

Megvizsgálva az együtthatókat a következőket lehet megfigyelni. Egyrészt míg a megye, illetve a határ menti település lakosságszáma pozitív irányba, addig a járás népessége negatív irányba befolyásolja a forgalmat. Ennek oka arra vezethető vissza, hogy a jelentősebb központtal rendelkező járások valószínűsíthetően gyengítik a határon átmenő ingázást, ugyanis egy nagyobb járásközpont feltehetően jobban vonzza az ingázókat, mint egy határon túli nagyváros. Bár számos, most magyarázott változó szignifikancia szintje magasabb, mint az elfogadható, azonban a modell kritériumrendszerének módosításával az e változókat jellemző értékek is az elfogadható tartományba kerülhetnek (így szignifikánsak lehetnek).

A korlátozások esetében az látható, hogy az éjszakai átjárás engedélyezése érdemben nem befolyásolja a forgalmat (ezt mutatja a negatív együttható), továbbá a jelenlegi kapacitások sem befolyásolják érdemben a forgalmat, nincsenek állandósult szűk keresztmetszetek. A híddal való ellátottság önmagában szintén nem okoz jelentős forgalomnövekedést, ugyanis itt a legkisebb vízfolyások is helyet kaptak, amelyek egyrészt nem képviselnek kiemelkedő elválasztó hatást, másrészt pedig a határok is felfoghatók egy akadályként, amelyen bizonyos pontokon lehet csak átkelni. Amenynyiben azonban a folyó szélességét is vizsgáljuk egyértelmüen pozitív hatást kapunk.

Az országokat tekintve a következőket lehet megfigyelni. Amennyiben a határátkelő valamely schengeni országba vezet, az nagy mértékü forgalomnövelő hatást jelent. Ezektől valamivel elmarad a Románia irányú forgalom. Illetve megfigyelhető, hogy Szerbia és Ukrajna hatása közel megegyezik. Továbbá látható még, hogy a Horvátország irányú forgalom jelentősen kisebb. 


\section{Közlekedésgazdaság}

Felmerülhet a kérdés, hogy a magyarázóváltozók száma magas a mintaelemszámhoz képest, azonban a magyarázóváltozók nagy száma a kategóriaváltozók dummy változóval való reprezentálása okán adódott.

\section{METODOLÓGIA}

E fejezetben a modellalkotás lépéseit ismertetjük. Az elözőekben bemutattuk, hogy jelen modell célja a határátkelők forgalmának becslése speciális térökonometriai eljárás alkalmazásával (2.2.3).

Modellünk azonosítása során a térökonometriai modell felállításának öt lépését követjük [1]:

1. súlymátrix előállítása,

2. Moran-féle I-próba meghatározása,

3. klasszikus lineáris regressziós modell felállítása,

4. térben eltolt lineáris regressziós modell felállítása,

5. a becslő modell felállítása.

\subsection{Súlymátrix előállítása}

A súlymátrix két alapvető típusát különböztetjük meg: a bináris vagy az inverz távolság alapú súlymátrix. A bináris szomszédsági mátrix 0 és 1 értékü elemekből épül fel (1 - ha a vizsgált térbeli reláció két eleme szomszédos, 0 - ha a vizsgált térbeli reláció két eleme nem szomszédos). Az inverz távolságalapú súlymátrix egyes celláiban a két elem távolságának inverz függvénye található. A súlymátrix egyes elemeit a következő képlet (1) segítségével lehet meghatározni [7]:

$$
w_{i, j}=\frac{1}{d(i, j)^{a}}
$$

Ahol a egy tetszőleges paraméter, a gyakorlatban értéke leggyakrabban 2. Jelen tanulmányban ettöl eltérünk, ugyanis az (1) távolság-hanyatlás görbeként is értelmezhető. [3] által ismertetett kutatás eredményei szerint a kitevő optimálisan 1,94 értéket vesz fel. Kutatásunk során is az $\mathrm{a}=1,94$ paramétert vizsgáljuk, amennyiben $i=j, w_{i j}=0$. A fentieken túl számos tanulmány javasolja a sorstandardizált súlymátrixok alkalmazását. Ennek lényege, hogy a mátrix minden egyes elemét elosztjuk adott sorhoz tartozó sorösszeggel. Ennek eredményeként minden sorra vonatkozóan a sorösszeg értéke 1, és $\sum_{i, j} w_{i j}=N$, ahol $N$ a megfigyelések száma [7].

\subsection{Moran-féle I-próba}

Annak eldöntésére, hogy egy térbeli adatsor elemei között autokorreláció van-e számos módszer mellett a leggyakrabban a Moran-féle I-próbát alkalmazzák. A képlete, sorstandardizált súlymátrix alkalmazása esetén, a következőképpen alakul [7]:

$$
I^{*}=\frac{\sum_{i, j}\left(w_{i j}\left(x_{i}-\mu\right)\left(x_{j}-\mu\right)\right)}{\sum_{i}\left(x_{i}-\mu\right)^{2}}
$$

ahol:

- $x_{i}, x_{j}$ : két pontban mért érték

- $\mu: x$ várható értéke

- $w_{i j}$ : térbeli súlymátrix egy eleme

Amennyiben az I* értéke nagyobb, mint a várható értékéé (3) akkor pozitív, ellenkező esetben negatív autokorrelációról beszélhetünk [7]:

$$
E\left(I^{*}\right)=\frac{-1}{N-1}
$$

\subsection{A klasszikus lineáris regressziós mo- dellek felépítése}

A térökonometriai modell azonosítása során az utolsó két lépésünk a klasszikus és a térben eltolt regressziós modell felépítése (4), amelynek eredményeként meghatározható a hibavektor. $\mathrm{Ez}$ alapján elvégezhetjük a térökonometriai modell felépítését [20]:

$y_{i}=\alpha+\sum_{l=1}^{k} \beta_{l} x_{l i}+u_{i}, i=1 . . N$

ahol:

- $y_{i}$ : az i-edik eredményváltozó,

- $x_{l i}$ : az i-edik eredményváltozóhoz tartozó l-edik magyarázó változó, 
- $\alpha$ : a konstans tag,

- $\beta_{l}$ : a l-edik magyarázó változóhoz tartozó együttható,

- k: magyarázó változók száma,

- $N$ : megfigyelések száma,

- $u_{i}: i$-edik hibatag.

A 3. lépés esetében az $y_{i}$ helyére az eredeti $y$ vektor értékei kerülnek, míg a 4 . lépésben a térben eltolt $W y$ értékek.

\subsection{A becslő modell felállítása}

A vizsgált probléma térökonometriai értékelésére alapvetően két eltérő módszertani keretrendszer alkalmazható. A térbeli késleltetés modellje (Spatial Autoregressive Models - SAR) lehetőséget teremt, hogy „egy változó bizonyos pontban mért értékét ugyanezen változónak a tér más pontjain mért értékeivel hozzuk összefüggésbe" [7]. E módszer esetében az idősorelemzés mintájára úgynevezett térbeli késleltetést alkalmazunk. A modellt az alábbi összefüggéssel írhatjuk le (5) [7]:

$$
\boldsymbol{y}_{(N \times 1)}=\rho \boldsymbol{W}_{(N \times N)} \boldsymbol{y}_{(N \times 1)}+\boldsymbol{X}_{(N \times K)} \boldsymbol{\beta}_{(K \times 1)}+\boldsymbol{\varepsilon}_{(N \times 1)}
$$

ahol:

$y$ : eredményváltozó értékeinek a vektora,

$\rho$ : térbeli autoregressziós paraméter,

$W$ : sorstandardizált súlymátrix,

$W y$ : az eredményváltozó térben késleltetett értékeinek a vektora,

$X$ : az exogén változók mátrixa,

$\beta$ : az exogén változók paramétervektora,

$\boldsymbol{\varepsilon}$ : a hibatagok vektora $\left(E\left(\varepsilon_{i}\right)=0, \mathrm{~V}\left(\varepsilon_{i}\right)=\sigma^{2}\right)$

E módszer tekintetében megállapítható, hogy a térbeli hatások modellezése során a klaszszikus lineáris regressziós modellbe egy új tagot veszünk fel. Mivel jelen esetben a legkisebb négyzetek módszere nem vezet eredményre, így a $\rho$ paraméter meghatározásához a maximum-likelihood módszer használata szükséges [7].

A másik eljárás a térbeli hiba autokorrelációs modellje (Spatial Error Models - SEM). E modell esetében a „regressziós egyenlet a magyarázó változóknak és a független változónak a tér- beli autokorreláció hatásaitól „megtisztított” viszonyát tárja elénk" [7]. Itt az autokorreláció tehát hibaként szerepel a modellben, ezért a hibatagok között jellemző térbeli autokorreláció korrekcióját szolgálja. A becslőmodell az alábbi összefüggéssel írható le (6):

$$
\begin{gathered}
\boldsymbol{y}_{(N \times 1)}=X_{(N \times K)} \boldsymbol{\beta}_{(K \times 1)}+\boldsymbol{\varepsilon}_{(N \times 1)} \\
\boldsymbol{\varepsilon}_{(N \times 1)}=\lambda \boldsymbol{W} \boldsymbol{\varepsilon}+\boldsymbol{\zeta}
\end{gathered}
$$

ahol:

- $\lambda$ : az autoregresszív hibatagok térben késleltetett értékeinek paramétere

- $\zeta$ : hibatagok vektora

Annak eldöntésére, hogy melyik modellt célszerü alkalmazni az $\mathrm{R}$ project beépített függvényét (spdep:LMtest) használtuk $[10,11,18$, 21]. A beépített függvény a megadott regreszsziós modellre meghatározza a Lagrangemultiplikátor tesztet, mind a SAR (LMlag), mind pedig a SER (LMerr) modellekre, valamint ezek robosztusságát (RLMerr, RLMlag) is megadja.

\section{AZ EREDMÉNYEK ISMERTETÉSE}

\subsection{A térökonometriai modell kiválasztása}

A térökonometriai modell kiválasztását a 2 . táblázat alapján végeztük el [18]. A vizsgálat során hat eltolásmátrixot vizsgáltunk, az alábbi paramétereknek megfelelően. A mátrix típusa kétféle lehet, sorstandardizált (W), illetve bináris (B) [19]. A hozzárendelés típusa négyféle lehet:

- Összes: minden határátkelő mindegyikre hatással van,

- Szomszéd: a szomszédos határátkelök hatnak egymásra,

- Főutakhoz: azon határátkelök vannak egymásra hatással, amelyek a két szomszédos másodrendü, vagy magasabb rangú határátkelök között vannak,

- Országhoz: azon határátkelők vannak egymásra hatással, amelyek ugyanazon ország felé biztosítanak átjárást, illetve mindkét irányban plusz egy-egy.

A minősítő táblázat a modellek azonosításán túl hat paramétert tartalmaz, azonban az al- 


\section{Közlekedésgazdaság}

2. táblázat: A térökonometriai modell kiválasztásának táblázata

(forrás: [18] és [19] cikkei alapján saját szerkesztés)

\begin{tabular}{|c|c|c|c|c|c|c|}
\hline & 0. modell & 1. modell & 2. modell & 3. modell & 4. modell & 5. modell \\
\hline Mátrix típusa & W & W & W & B & W & B \\
\hline Hozzárendelés & Összes & Szomszéd & Főutakhoz & Országhoz & Országhoz & Föutakhoz \\
\hline Moran I & $-0,1392$ & $-0,1841$ & $-0,1768$ & $-0,0386$ & $-0,1474$ & $-0,0185$ \\
\hline Moran I p-értéke & 0,3296 & 0,4276 & 0,3205 & 0,4534 & 0,3811 & 0,2924 \\
\hline LMerr p-érték & 0,0796 & 0,0981 & 0,0668 & 0,1494 & 0,0816 & 0,7544 \\
\hline LMlag p-érték & 0,6192 & 0,9014 & 0,7861 & 0,7901 & 0,6303 & 0,0594 \\
\hline RLMerr p-érték & 0,0175 & 0,0364 & 0,0188 & 0,0153 & 0,0172 & 0,0086 \\
\hline RLMlag p-érték & 0,0933 & 0,1982 & 0,1350 & 0,0492 & 0,0899 & 0,0013 \\
\hline
\end{tabular}

kalmazandó eljáráshoz csupán csak az utolsó négyet kell elsődlegesen figyelembe venni, ugyanis a másik kettő a Moran-I próba jóságát írja le, ami ha nem megfelelö, akkor egyik metódus sem alkalmazható. A paraméterek között az első sorban a Moran-I értéke látható, míg ennek p-értékét a második sor mutatja. A harmadiktól a hatodik sorig vannak azon paraméterek, amelyek elsődlegesen meghatározzák a modell típusát. Az első két sor az általános teszt, míg a második két teszt a robosztus teszt p-értékeit tartalmazza. Amelyik módszer p-értékei kedvezőbbek, azt a modellt célszerü alkalmazni [18].

\subsection{Modellek összehasonlítása}

A 2. táblázat alapján csak az 5. modellt célszerü a térbeli késleltetés autokorrelációs modelljével lefuttatni (sar25), azonban a sorstandardizált súlymátrixok alkalmasak lehetnek a SEM eljárások számára. A további vizsgálatok azt mutatták, hogy a 4 . modell nem vezet eredményre, így csak a maradék három mátrixhoz rendelhető SEM metódus (errorsalm20, errorsalm21, errorsalm22). Az összehasonlítást a 3. táblázat foglalja össze, ahol az egyes modellek az ismertetett azonosítókkal kerültek megkülönböztetésre.

Mint ahogyan az 1. táblázatban itt is (3. táblázat:) az egyes sorokban az együtthatók és a hozzájuk tartozó p-értékek láthatók. A 4. táblázat az egyes modellek összehasonlítását tartalmazza. A $\rho / \lambda$ sor az aktuális modellre vonatkozó térbeli autokorrelációs paramétert mutatja. A harmadik sor ennek a p-értékét adja meg. A negyedik sor a logaritmus likelihood függvény értékét, míg az ötödik sor az ebből számított AIC (Akaike Information Criteria) értékét mutatja. Általánosan elmondható, hogy ezek abszolút értékben minél kisebbek, annál jobbnak tekinthető a modell [5].

Az együtthatókról megállapítható, hogy öszszességében a hatások nem módosulnak a klasszikus modellhez képest. Az egyetlen SAR modellt vizsgálva (sar25) az látható, hogy Szerbia együtthatója csökkent Ukrajnához képest. Ezzel szemben a SEM modellek esetében az országok hatásai visszaesnek, csupán Ausztria és Szlovénia tartja meg erős helyzetét, amiből arra lehet következtetni, hogy a többi ország esetében jelentősebbek a térbeli hatások.

Megbecsülve a modell alapján várható forgalomlefolyást a következőket lehet megállapítani. Vannak kiemelkedően túlterhelt határátkelöhelyeink, amelyek a fontosabb első és másodrendü főutak (például: 84, 42, 49, 56), illetve a Duna-hidak $(13,14)$, a Dráva-híd Drávaszabolcsnál (58) és az új Ipoly-hidak (22103 illetve 22105). A 84-es szerepét Sopron közelsége biztosítja, a 42-es és a 49-es a Románia, az 56-os a Horvátország felé kialakítandó főbb autópályák (M3, M4 illetve M6) helyettesítő foútjai. Természetesen a legtúlterheltebb út a modell alapján egyértelműen az M1-es autópálya. Mindezek alapján arra következtet- 
3. táblázat: A térbeli modellek összehasonlítása (forrás: saját szerkesztés)

\begin{tabular}{|c|c|c|c|c|c|c|c|c|c|c|c|c|c|}
\hline & & \multicolumn{4}{|c|}{ Térbeli késleltetés modellje az 5-ös mátrixra } & \multicolumn{4}{|c|}{ Térbeli hiba modellje a 0-ás mátrixra } & \multicolumn{4}{|c|}{ Térbeli hiba modellje a 1-es mátrixra } \\
\hline & & Együttható & Std. Hiba & $\operatorname{Pr}(>|z|)$ & & Együttható & Std. Hiba & $\operatorname{Pr}(>|z|)$ & & Együttható & \begin{tabular}{l|l} 
Std. Hiba \\
\end{tabular} & $\operatorname{Pr}(>|z|)$ & \\
\hline Tengelymetszet & & 2461,30 & 3526,50 & 0,4852 & & 2685,40 & 3232,80 & 0,4061 & & 2454,50 & 3498,10 & 0,4829 & \\
\hline \multirow{3}{*}{ Magyar lakosságszám } & Megye & $2,53 \mathrm{E}-03$ & $1,43 \mathrm{E}-03$ & 0,0774 & & $2,85 \mathrm{E}-03$ & $1,10 \mathrm{E}-03$ & 0,0096 & *** & $3,00 \mathrm{E}-03$ & $1,21 \mathrm{E}-03$ & 0,0135 & * \\
\hline & Járás & $-4,43 \mathrm{E}-03$ & $6,88 \mathrm{E}-03$ & 0,5192 & & $-1,11 \mathrm{E}-02$ & $5,17 \mathrm{E}-03$ & 0,0319 & $*$ & $-7,22 \mathrm{E}-03$ & $5,78 \mathrm{E}-03$ & 0,2116 & \\
\hline & Település & $1,57 \mathrm{E}-01$ & $3,25 \mathrm{E}-02$ & $1,39 \mathrm{E}-06$ & **** & $1,37 \mathrm{E}-01$ & $2,82 \mathrm{E}-02$ & $1,18 \mathrm{E}-06$ & **** & $1,49 \mathrm{E}-01$ & 2,99E-02 & $6,44 \mathrm{E}-07$ & $* * *$ \\
\hline \multicolumn{2}{|c|}{ Szomszédos NUTS-3 régió lakossága } & $1,73 \mathrm{E}-03$ & $3,39 \mathrm{E}-03$ & 0,6106 & & $6,93 \mathrm{E}-03$ & $2,71 \mathrm{E}-03$ & 0,0105 & * & $5,05 \mathrm{E}-03$ & $2,97 \mathrm{E}-03$ & 0,0885 & $*$ \\
\hline \multirow{5}{*}{ Határátkelö tulajdonságai } & Nyitva tartás & $-11,22$ & 12,34 & 0,3633 & & $-15,25$ & 11,80 & 0,1962 & & $-14,62$ & 12,36 & 0,2371 & \\
\hline & Kapacitás & $-0,42$ & 0,36 & 0,2434 & & $-0,70$ & 0,33 & 0,0312 & * & $-0,60$ & 0,35 & 0,0852 & $*$ \\
\hline & Összsúly korlát & 11,53 & 16,54 & 0,4858 & & $-7,14$ & 14,05 & 0,6112 & & 7,18 & 15,02 & 0,6328 & \\
\hline & Tehergépjármü korlátozás & 1267,70 & \begin{tabular}{l|l|}
779,93 \\
\end{tabular} & 0,1041 & & $-1694,40$ & 729,89 & 0,0203 & * & $-344,17$ & $\begin{array}{ll}759,27 \\
\end{array}$ & 0,6503 & \\
\hline & Autóbusz korlátozás & $-1511,70$ & 974,45 & 0,1208 & & 443,13 & 957,01 & 0,6433 & & $-605,54$ & 982,10 & 0,5375 & \\
\hline \multicolumn{2}{|r|}{ the } & $-595,37$ & 664,96 & 0,3706 & & $-1121,30$ & 614,71 & 0,0681 & & $-969,80$ & 626,45 & 0,1216 & \\
\hline \multirow{6}{*}{$\begin{array}{c}\text { Országra kategória dummy } \\
\text { változók }\end{array}$} & Ausztria & 4474,60 & 1682,60 & 0,0078 & *** & 7586,30 & 1306,90 & 6,44E-09 & **** & 6815,80 & 1460,80 & $3,07 \mathrm{E}-06$ & **** \\
\hline & Horvátország & $-1440,70$ & 1551,10 & 0,3530 & & $-83,72$ & 1256,60 & 0,9469 & & $-486,16$ & 1351,90 & 0,7191 & \\
\hline & Románia & 515,42 & 1546,60 & 0,7389 & & 297,00 & 1283,60 & 0,8170 & & 555,32 & 1353,10 & 0,6815 & \\
\hline & Szerbia & $-309,49$ & 1524,20 & 0,8391 & & 1457,00 & 1185,20 & 0,2189 & & 751,03 & 1328,70 & 0,5719 & \\
\hline & Szlovákia & 1339,80 & 1944,60 & 0,4908 & & 682,90 & 1620,80 & 0,6735 & & 1108,30 & 1707,60 & 0,5163 & \\
\hline & Szlovénia & 3473,10 & 1821,40 & 0,0566 & & 7036,90 & 1395,90 & $4,63 \mathrm{E}-07$ & **** & 5908,70 & 1558,30 & $1,50 \mathrm{E}-04$ & **** \\
\hline \multirow{3}{*}{$\begin{array}{c}\text { Európai nemzetközi E-út } \\
\text { hálózat }\end{array}$} & A osztályú föút & 4317,30 & 1340,30 & 0,0013 & ** & 3621,20 & 1122,70 & 0,0013 & *** & 3713,30 & 1247,50 & 0,0029 & $* *$ \\
\hline & A osztályú kiegészítö & $-473,07$ & 1132,00 & 0,6760 & & \begin{tabular}{ll|}
$-782,20$ \\
\end{tabular} & 1041,50 & 0,4526 & & $\begin{array}{l}-724,15 \\
\end{array}$ & 1077,40 & 0,5015 & \\
\hline & B osztályú & 1844,10 & 1506,70 & 0,2210 & & 2628,40 & 1400,70 & 0,0606 & & 2427,90 & 1527,90 & 0,1121 & \\
\hline \multirow{4}{*}{$\begin{array}{l}\text { Magyar úthálózat dummy } \\
\text { változói }\end{array}$} & Autópálya & 8067,10 & 2881,10 & 0,0051 & ** & 10947,00 & 2488,40 & 1,09E-05 & **** & 9901,50 & 2722,50 & $2,76 \mathrm{E}-04$ & **** \\
\hline & Autóút & 4874,80 & 3170,00 & 0,1241 & & 4564,50 & 2787,90 & 0,1016 & & 4320,00 & 3035,40 & 0,1547 & \\
\hline & Föút & 2422,90 & 1072,90 & 0,0239 & * & 2784,10 & 961,13 & 0,0038 & *** & 2657,90 & 1007,00 & 0,0083 & $* *$ \\
\hline & Egyéb & 642,26 & 805,12 & 0,4250 & & 1062,70 & 691,26 & 0,1242 & & 891,38 & 730,66 & 0,2225 & \\
\hline \multirow{4}{*}{$\begin{array}{c}\text { Szomszédos országok } \\
\text { úthálózatának dummy változói }\end{array}$} & Elsörendü fót & $-2324,10$ & 2610,60 & 0,3733 & & $-638,81$ & 2403,70 & 0,7904 & & $-1526,20$ & 2548,40 & 0,5493 & \\
\hline & Másodrendü fơút & $-3445,50$ & 2628,20 & 0,1899 & & $-3525,00$ & 2404,90 & 0,1427 & & $-3705,30$ & 2576,40 & 0,1504 & \\
\hline & Összekötő út & $-4756,00$ & 2699,00 & 0,0780 & & $-6211,60$ & 2452,20 & 0,0113 & * & $-5657,70$ & 2641,60 & 0,0322 & $*$ \\
\hline & Helyi út & $-5317,30$ & 2686,60 & 0,0478 & * & $-6600,00$ & 2488,90 & 0,0080 & *** & $\begin{array}{ll}-6192,40 \\
\end{array}$ & 2667,10 & 0,0202 & $*$ \\
\hline Folyószélesség & & 4,40 & 3,12 & 0,1580 & & 5,17 & 2,72 & 0,0569 & & 5,03 & 2,80 & 0,0724 & \\
\hline & & Térbeli hi & ba modellje a & 2-es mátrixr & & Térbeli hi & ba modellje a & -es mátrixr & & & & & \\
\hline & & Együttható & Std. Hiba & $\operatorname{Pr}(>|z|)$ & & Együttható & Std. Hiba & $\operatorname{Pr}(>|z|)$ & & & & & \\
\hline Tengelymetszet & & 2068,20 & 3415,20 & 0,5448 & & 2941,90 & 3242,50 & \begin{tabular}{|c|}
0,3643 \\
\end{tabular} & & & & & \\
\hline & Megye & $3,03 \mathrm{E}-03$ & $1,15 \mathrm{E}-03$ & 0,0085 & ** & $2,85 \mathrm{E}-03$ & $1,09 \mathrm{E}-03$ & 0,0091 & *** & & & & \\
\hline Magyar lakosságszám & Járás & $-8,33 \mathrm{E}-03$ & $5,48 \mathrm{E}-03$ & 0,1287 & & $-1,10 \mathrm{E}-02$ & $5,14 \mathrm{E}-03$ & 0,0319 & * & & & & \\
\hline & Település & $1,49 \mathrm{E}-01$ & $2,85 \mathrm{E}-02$ & $1,85 \mathrm{E}-07$ & **** & $1,37 \mathrm{E}-01$ & $2,82 \mathrm{E}-02$ & $1,16 \mathrm{E}-06$ & **** & & & & \\
\hline Szomszédos NUTS-3 régió lako & ossága & $6,34 \mathrm{E}-03$ & $2,82 \mathrm{E}-03$ & 0,0243 & * & $6,83 \mathrm{E}-03$ & $2,68 \mathrm{E}-03$ & 0,0107 & * & & & & \\
\hline & Nyitva tartás & $-14,50$ & 12,05 & 0,2289 & & $-16,70$ & 11,86 & 0,1593 & & & & & \\
\hline & Kapacitás & $-0,64$ & 0,34 & 0,0594 & & $-0,73$ & 0,33 & 0,0255 & * & & & & \\
\hline Határátkelő tulajdonságai & Összsúly korlát & 4,16 & 14,82 & 0,7789 & & $-6,93$ & 14,08 & 0,6227 & & & & & \\
\hline & Tehergépjármủ korlátozás & $-1170,60$ & 763,91 & 0,1254 & & $-1708,30$ & 730,04 & 0,0193 & * & & & & \\
\hline & Autóbusz korlátozás & 25,24 & 977,35 & 0,9794 & & 478,98 & 956,51 & 0,6165 & & & & & \\
\hline Hid & & $-1034,40$ & 619,17 & 0,0948 & & $-1147,00$ & 614,04 & 0,0618 & & & & & \\
\hline & Ausztria & 7414,10 & 1376,20 & $7,15 \mathrm{E}-08$ & **** & 7622,50 & 1279,20 & $2,54 \mathrm{E}-09$ & **** & & & & \\
\hline & Horvátország & $-147,46$ & 1259,20 & 0,9068 & & 92,25 & 1199,80 & 0,9387 & & & & & \\
\hline Országra kategória dummy & Románia & 543,54 & 1281,20 & 0,6714 & & 395,29 & 1226,40 & 0,7472 & & & & & \\
\hline változók & Szerbia & 1238,30 & 1244,60 & 0,3197 & & 1501,50 & 1139,00 & 0,1874 & & & & & \\
\hline & Szlovákia & 902,14 & 1618,80 & 0,5773 & & 789,02 & 1582,30 & 0,6180 & & & & & \\
\hline & Szlovénia & 6636,30 & 1462,70 & $5,70 \mathrm{E}-06$ & **** & 7111,80 & 1360,50 & $1,72 \mathrm{E}-07$ & **** & & & & \\
\hline & A osztályú fóut & 3370,60 & 1194,70 & 0,0048 & *** & 3599,80 & 1113,30 & 0,0012 & ** & & & & \\
\hline $\begin{array}{l}\text { Európaı nemzetkózi E-út } \\
\text { hálózat }\end{array}$ & A osztályú kiegészítö & $-665,69$ & 1052,00 & 0,5269 & & $-817,29$ & 1043,60 & 0,4335 & & & & & \\
\hline & B osztályú & 2653,20 & 1507,40 & 0,0784 & & 2689,30 & 1429,50 & 0,0599 & & & & & \\
\hline & Autópálya & 10494,00 & 2652,20 & $7,59 \mathrm{E}-05$ & **** & 10942,00 & 2485,40 & $1,07 \mathrm{E}-05$ & **** & & & & \\
\hline Magyar úthálózat dummy & Autóút & 4422,00 & 2965,60 & 0,1359 & & 4614,70 & 2808,50 & 0,1004 & & & & & \\
\hline változói & Föút & 2683,40 & 990,41 & 0,0067 & *** & 2789,30 & 963,35 & 0,0038 & *** & & & & \\
\hline & Egyéb & 965,48 & 713,59 & 0,1761 & & 1035,50 & 689,46 & 0,1331 & & & & & \\
\hline & Elsörendü föút & $-1201,80$ & 2492,00 & 0,6296 & & $-651,23$ & 2401,90 & 0,7863 & & & & & \\
\hline Szomszédos országok & Másodrendű foút & $-3677,10$ & 2510,00 & 0,1429 & & $-3543,10$ & 2399,80 & 0,1398 & & & & & \\
\hline úthálózatának dummy változói & Összekötö út & $-5971,50$ & 2565,60 & 0,0199 & * & $-6244,50$ & 2452,40 & 0,0109 & * & & & & \\
\hline & Helyi út & $-6352,60$ & 2601,10 & 0,0146 & * & $-6643,80$ & 2489,80 & 0,0076 & ** & & & & \\
\hline Folyószélesség & & 5,28 & 2,75 & 0,0550 & . & 5,33 & 2,70 & 0,0481 & * & & & & \\
\hline
\end{tabular}

hetünk, hogy a határ felé irányuló gyorsforgalmi közúthálózat kapacitásának bővítése indokolt lehet, ugyanis a tervezett autópályahelyettesítő határátkelők a legtúlterheltebbek (M3-41, M4-42, M6-56, M85-84), valamint elmondható, hogy a nagyobb folyókon (Duna, Dráva, Ipoly) új hidak építése válhat szükségessé. A modellel kimutatható továbbá az M15-ös és az M70-es autóutak bővítésé- nek szükségessége, amely összhangban van a hazai infrastruktúra-fejlesztésekkel [13, 14].

Ezzel szemben egyes határátkelők esetében a jelenlegi forgalom elmarad a becsülttől. Ezek jellemzően a Szerbia és Horvátország felé vezető fontosabb utak (M5, M7, 6), de ide tartozik például a 26-os is. Ennek oka, hogy ezen irányok inkább kiesnek a nemzetközi fö irányokból. 


\section{Közlekedésgazdaság}

4. táblázat: A térbeli modellek összehasonlítása (forrás: [19] alapján saját szerkesztés)
\begin{tabular}{|l|r|r|r|r|r|}
\hline & sar5 & errorsalm0 & errorsalm1 & errorsalm2 & errorsalm4 \\
\hline$R^{2}$ & 0,7839 & 0,8286 & 0,7995 & 0,8118 & 0,8291 \\
\hline$\rho / \lambda$ & 0,0343 & $-0,6004$ & $-0,2909$ & $-0,4244$ & $-0,5836$ \\
\hline p-érték & 0,0820 & $1,04 \mathrm{E}-04$ & $1,24 \mathrm{E}-02$ & $1,95 \mathrm{E}-03$ & $1,30 \mathrm{E}-04$ \\
\hline$L_{c}$ & $-931,1929$ & $-925,1766$ & $-929,5786$ & $-927,9058$ & $-925,3812$ \\
\hline AIC & 1924,4 & 1912,4 & 1921,2 & 1917,8 & 1912,8 \\
\hline
\end{tabular}

\subsection{Kiemelt hatások vizsgálatának össze- foglalása}

A megvizsgált nemzetközi döntés-elökészítő, illetve helyzetfeltáró tanulmányok $[16,17]$ alapján az alábbi öt kiemelt tényezőt azonosítottuk, amelyek vizsgálatát kiemelten fontosnak minősítettük a határátkelők forgalmának becslésére vonatkozóan:

- híddal való ellátottság,

- út típusa,

- európai utak hálózata,

- célország,

- schengeni-határok.

A híddal való ellátottság problémájának megértéséhez célszerü figyelembe vennünk, hogy az a modell alapján nem gyakorol szignifikáns hatást a forgalomra. A közlekedőknek kevésbé lényeges, hogy mi képezi az elválasztó hatást/ kapacitáscsökkenést. Legyen az egy határátkelő szakasz vagy a részhálózatokat elválasztó természetes képződmény (pl. folyó, hegy, völgy stb.)

Az úthálózat hatásai az előzetes elvárásoknak megfelelöen alakultak. Az együtthatók megfelelően megadják, hogy minél magasabb kategóriájú egy foút, annál nagyobb rajta a forgalom. Azonban e definícióértékü megállapítást számos körülmény árnyalja. Az első körülmény, hogy az első- és másodrendü föutak, illetve az összekötő és bekötő utak közötti különbség nem mutatható ki a modellel. Ez a korábbi megállapításokhoz igazodva két okra vezethetö vissza. Az egyik, hogy az elsőrendü utak harmada mellett van párhuzamos autópálya, ahová átterelődött a forgalom, míg a másodrendủ foutakra ugyanez nem mondható el, illetve az említett kategóriapárok kö- zött nincs látványos különbség. Fentieken túl hangsúlyos tényező, hogy a szomszédos országok határhoz vezető útjainak esetében nem lehet a modell szerint különbséget tenni az autópályák és az autóutak között. Ennek oka, hogy Magyarországon minden gyorsforgalmi út a határ túloldalán autópályaként folytatódik, és ez visszafelé is igaz, vagyis minden külföldről jövő autópálya gyorsforgalmi útként folytatódik hazánkban. Így a lineáris összefüggés elkerülése okán a modellben a külföldi oldalon csak a gyorsforgalmi út, mint kategória, volt vizsgálható.

Az európai utak rendszerében ugyanezen minta már nem figyelhető meg. Itt az A osztályú összekötő utak együtthatója szignifikánsan negatívra adódott a rendszerbe nem bevont utakhoz képest. Ezen hatás okainak felkutatása jelentősen túlmutat jelen cikk célkitűzésein, ugyanis alaposabb egyedi vizsgálatokkal lehetne meghatározni (például a nemzetközi szakirodalomból ismert lehetőségelemzéssel). A probléma általános szemléltetését mutatja a 3. ábra, ami a nemzetközi E-úthálózat egyes útkategóriáin belül előforduló úttípusok megoszlását szemlélteti.

Mint a 3. ábrán látható az A osztályú összekötő utak legtöbbje elsőrendü föutakon fordul elő. Ami azonban nem látható, hogy ezek azon elsőrendü föutak, amelyekkel párhuzamosan még nem épült autópálya. Továbbá két esetben (M7, 42) is megfigyelhetö, hogy a határátkelö egyszerre része az A osztályú fóntnak és az A osztályú összekötő útnak. Ezzel szemben a B osztályú utak közé rendszerint kiegészítő gyorsforgalmi útszakaszok (M70 vagy a 41-es főut), illetve nagy forgalmú főutak (14-es fóút) tartoznak. 


\section{3. ábra: A nemzetközi E-úthálózaton beluili útkategóriák megoszlása (forrás: saját szerkesztés)}

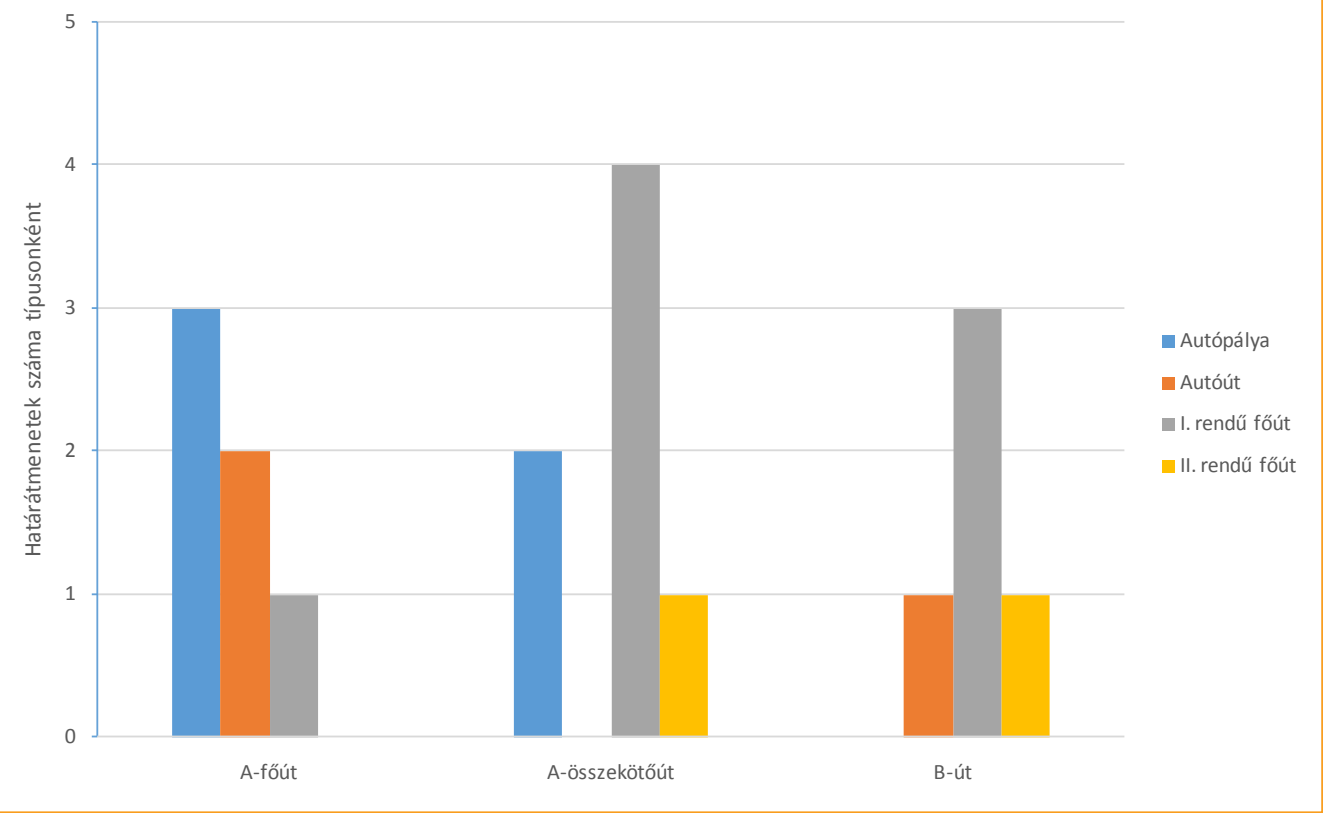

Az utolsó két szempont a célország és a schengeni országok hatásai. Mivel ezeket a modellben sem lehetett szétbontani, így itt is egyben kerülnek bemutatásra. A schengeni országokkal meglévő erős kapcsolat hatását a becslő modell vonatkozó együtthatói is tükrözik. Azokat Románia követi, mint 2007-ben csatlakozott EU tag. Ukrajna és Szerbia hatása, minthogy nem tagjai a közösségnek, nagyjából megegyezik, ezen csak a térbeli modell hatásai változtatnak valamennyit. Azonban a Horvátország felé irányuló forgalom jelentősen elmarad a többi szomszédos országtól, amelynek oka, hogy az Adriai-tenger horvát kikötői által generált forgalom elmarad a többi iránytól.

\section{5. ÖSSZEGZÉS}

Megállapítható, hogy a térökonometriai modell felállítását követően (4.1. fejezet) a becslőmodell alkalmazásának eredményeként a határátkelőkre vonatkozóan gyenge az autokorrelációs kölcsönhatás. Megvizsgálva a kiemelt tényezőként azonosított magyará- zó változók hatását, rögzíthetjük, hogy az elválasztó hatások modellezése során hasonló hatást mutat a hidak és a határátkelőhelyek vizsgálata. A kettő együttes alkalmazása esetén többlethatás nem mutatkozik. A továbblépés tekintetében több jövőbeni kutatási célkitüzés is kirajzolódott. Világossá vált, hogy az európai úthálózat szélesebb körü vizsgálata indokolt, hiszen a hatások részletes értékelése a hatékony hálózatfejlesztési célok megvalósítása szempontjából alapvető jelentőségü összefüggéseket tárhat fel. Emellett a tranzitforgalmak mélyebb vizsgálata is szükséges, hiszen a nemzetközi kapcsolatok és kereskedelem szempontjából kiemelten fontos a hazánkba érkező, illetve az átmenő nemzetközi forgalom struktúráját alakító hatások feltárása. Fentieken túl célunk az országok dummy változóval való leképzése mellett a nemzetközi szakirodalomban tárgyalt egyéb módszerek (pl. gazdasági tényezők hatásának leképezése) alkalmazására irányuló kutatások megvalósítása. 


\section{Közlekedésgazdaság}

\section{FELHASZNÁLT IRODALOM}

[1] L. Anselin. Spatial Econometrics: Methods and Models. Dordrecht, Kluwer Academic Publishers, (1988). ISBN: 90-247-3735-4

[2] A. de Palma, R. Lindsey, E. Quinet és R. Vickerman (szerk.). Handbook of Transportation Economics. Cheltenham Glos, Edward Elgar Publishing Limited, (2011) pp. 84-87. ISBN: 9781 847202031

[3] P. Hagget (szerk.). Geográfia. Globális szintézis. Budapest, TYPOTEX Kiadó, (2006). pp. 398-399. ISBN: $963954860 \mathrm{X}$

[4] Illés I. Regionális gazdaságtan - Területfejlesztés. Budapest, TYPOTEX, (2008) pp. 190-205. ISBN: 9789632790046

[5] A. C. Cameron, P. K. Trivedi. Microeconometrics: Methods and Applications. New York, Cambridge University Press, (2005). pp. 278-279. ISBN: 978-0-521-84805-3

[6] M. D. Meyer és E. J. Miller. Urban Transportation Planning. McGraw-Hill, 2nd edition, (2000). ISBN: 0-07-242332-3

[7] Varga A. Térökonometria. Statisztikai szemle, Vol. 80, No. 4, (2002) pp. 354-370. ISSN: 0039-0690

[8] M. Moniruzzaman, H. Maoh és W. Anderson. Short-term prediction of border crossing time and traffic volume for commercial trucks: A case study for the Ambassador Bridge. Transportation Research Part C: Emerging Technologies, Vol. 63, (2016) pp. 182-194. ISSN: 0968-090X

[9] H. F. Maoh, S. A. Khan és W. P. Anderson. Truck movement across the Canada-US border: The influences of 9/11 and other factors. Journal of Transport Geography, Vol. 53, (2016) pp. 12-21. ISSN: 0966-6923 DOI: http://doi.org/f8smfd

[10] R. Bivand, G. Piras: Comparing Implementations of Estimation Methods for Spatial Econometrics. Journal of Statistical Software, Vol. 63, No. 18, (2015) pp. 1-36. ISSN: 1548-7660, DOI: http://doi. org/cqxi

[11] R. S. Bivand, J. Hauke, és T. Kossowski: Computing the Jacobian in Gaussian spatial autoregressive models: An illustrated comparison of available methods. Geographical Analysis, Vol. 45, No. 2, (2013) pp. 150-179. ISSN: 1538-4632, DOI: http://doi.org/cqxk

[12] N. Limão és A. J. Venables: Infrastructure, geographical disadvantage, transport costs and trade. World Bank Economic Review, Vol. 15, (2001) pp. 451-479. ISSN: 1564-698X

[13] Szalóki F. M15 expressway- upgrade and widening to a $2+2$ traffic lanes motorway between M1 motorway and Rajka (HUSK border) XV. Európai Közlekedési Kongresszus és X. Budapesti Nemzetközi Útügyi Konferencia, Budapest (2017) pp. 12-17

[14] Szalóki F. M70 expressway- upgrade and widening to a $2+2$ traffic lanes motorway between Letenye and Tornyiszentmiklós (HU-SL border) XV. Európai Közlekedési Kongresszus és X. Budapesti Nemzetközi Útügyi Konferencia, Budapest (2017) pp. 18-24

[15] One Planet Mérnökiroda Kft. Az országos közutak 2015. évre vonatkozó keresztmetszeti forgalma. Budapest, Magyar Közút Nonprofit Zártkörüen Működő Részvénytársaság, (2016)

[16] Japan International Cooperation Agency, Oriental Consultants Global Co., LTD., and Padeco Co., LTD. Preparatory Survey on the Cross-Border Road Network Improvement Project - Final Report, Volume 1: Main Report. Dhaka, Bangladesh, Roads and Highways Department, Ministry of Road Transport and Bridges, The People's Republic of Bangladesh, (2016)

[17] United Nations Economic and Social Commission for Asia and the Pacific The Road Networks connecting China, Kazakhstan, Mongolia, the Russian Federation, and the Korean Peninsula. UNESCAP, (2001)

[18] Ignacio Sarmiento-Barbieri: An Introduction to Spatial Econometrics in R. Champaign, IL, University of Illinois, (2016) URL: http://www.econ.uiuc. edu/ lab/workshop/Spatial_in_R.html

[19] Roger Bivand et. al.: Spatial Dependence: Weighting Schemes, Statistics and Models. Bergen, Norges Handelshøyskole, 
(2017) URL: https://cran.r-project.org/ web/packages/spdep/spdep.pdf

[20] Elek Péter, Bíró Anikó: Ökonometria. Budapest, Eötvös Lóránt Tudományegyetem Közgazdaságtudományi Tanszék, (2010) URL: http://www.tankonyvtar.hu/hu/tartalom/tamop425/0041_okonometria/01_ het_okonometria_vegleges_1_1.html

[21] R Core Team: A language and environment for statistical computing. Wien, $\mathrm{R}$ Foundation for Statistical Computing, (2017) URL: https://www.r-project.org/

[22] MTI közszolgálat. http://mti.hu/mti/ Default.aspx (letöltve: 2017. 04. 23.) (MTI közszolgálat, 2017)
[23] Egységes Hídnyilvántartási Rendszer. http://www.hidadatok.hu/ (letöltve: 2017. 05. 12.)

[24] Magyarország Helységnévtára. https:// www.ksh.hu/apps/hntr.main (letöltve: 2017. 05. 12.)

[25] Slovenská správa ciest. http://www.ssc.sk/ sk/cinnosti/rozvoj-cestnej-siete/dopravneinzinierstvo/celostatne-scitanie-dopravyv-roku-2015.ssc (letöltve: 2017. 05. 12.)

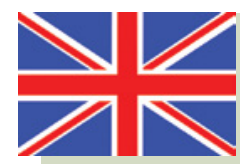

\section{Evaluating the Hungarian Border Crossings from Spatial Econometric Point of View}

The evaluation on the border crossings, as the objects to reduction the separation influence, is really important for our country, to evaluate the relationship of the neighbouring and other nearby countries and international economic centers with Hungary. In our country's life the cross-border partnerships have an important role because of historical and cultural causes. In the current paper, our task is to investigate changes of the crossborder traffic, with the help of the spatial econometrics. The objective is to show the influence of five outstanding areas on the crossing traffic, and to investigate the spatial relationship between them.

\section{Bewertung der ungari- schen Grenzübergänge aus der Sicht der räumlichen Ökonometrie}

Die Bewertung der Grenzübergänge, als Objekte zur Reduzierung des Trennungseinflusses, ist für unser Land wirklich wichtig, um die Beziehungen zwischen den Nachbarländern und anderen nahe liegenden Ländern sowie internationalen Wirtschaftszentren und Ungarn zu bewerten. Im Leben unseres Landes spielen die grenzüberschreitenden Partnerschaften aufgrund historischer und kultureller Ursachen eine wichtige Rolle. In dieser Arbeit haben wir uns die Aufgabe vorgenommen, Veränderungen des grenzüberschreitenden Verkehrs mit Hilfe der räumlichen Ökonometrie zu untersuchen. Unser Ziel war dabei, den Einfluss von fünf herausragenden Bereichen auf den grenzüberquerenden Verkehr aufzuzeigen und deren räumliche Beziehung zu untersuchen. 